\title{
The role of intradermal proliferation of T-cells in the pathogenesis of psoriasis* $^{*}$
}

\author{
Vladislav R. Khairutdinov ${ }^{1}$ \\ Irena E. Belousova ${ }^{1}$ \\ Alexey V. Samtsov ${ }^{1}$
}

\author{
Anastasiya F. Mikhailichenko ${ }^{1}$ \\ Ekatherina Sh. Kuligina ${ }^{2}$ \\ Evgeny N. Imyanitov ${ }^{2,3}$
}

DOI: http:/ / dx.doi.org/10.1590/abd1806-4841.20175765

\begin{abstract}
BACKGROUND: Psoriasis is a common immune-mediated chronic inflammatory disease of the skin and joints, affecting $1-3 \%$ of the population. It is generally accepted that the pathogenesis of psoriasis involves accumulation of effector T-cells within lymph nodes and their subsequent migration into the skin through the blood system. Here we provide evidence that psoriatic plaque itself may serve as a source of inflammatory T-cells.

OвjестіvE: We examined the intradermal proliferation of T-cells and the number of effector/memory (CD45RO+) T-cells in the skin of psoriatic patients at different periods of the disease.

METHODS: Skin samples were obtained from 41 patients with progressive psoriatic lesions; 18 of these patients also donated skin specimens during the remission of the disease. The control group consisted of 16 healthy subjects. Ki- 67 immunohistochemical staining was applied to detect proliferating cells, CD3 served as a T-cell marker, and CD45RA and CD45RO antibodies were utilized to discriminate between naive and effector/memory T-cells, respectively.

REsults: Progressive psoriatic lesions demonstrated Ki67 staining both in keratinocytes and in the CD3e+ cells of dermal infiltrate. Median count of CD45RO+ cells per microscopic field was 15 in healthy controls, 59 in patients in remission and 208 in progressive psoriatic plaques. The observed differences demonstrated high level of statistical significance.

StUDY LIMITATIONS: Limited number of analyzed patients..

CONCLUSION: Progressive phase of psoriasis is characterized by intradermal proliferation of T-cells. Spots of regressed psoriatic lesions contain high number of CD45RO+ cells, which are likely to render an immunological memory.
\end{abstract}

Keywords: Cell proliferation; Psoriasis; T-Lymphocytes

\section{INTRODUCTION}

Psoriasis is a common immune-mediated chronic inflammatory disease of the skin and joints, affecting 1-3\% of the population. ${ }^{1}$ The pathogenesis of psoriasis involves activation of Langerhans cells in the epidermis followed by their migration into the dermis; these cells subsequently relocate to draining lymph nodes and present antigens to naive T-cells. ${ }^{2}$ This induces the differentiation of $\mathrm{Th}_{0}$ cells into $\mathrm{Th}_{1}$ and $\mathrm{Th}_{17}$ lymphocytes; the mobilization of the latter to the skin results in a formation of psoriatic plaque. ${ }^{3,4} \mathrm{An}-$ tigen-specific differentiation is accompanied by the change of T-cell phenotype from $\mathrm{CD}^{+} \mathrm{CD}^{+} 5 \mathrm{RA}^{+}$(naive) to $\mathrm{CD}^{+} \mathrm{CD}^{+} 5 \mathrm{RO}^{+}$(effector/ memory) ${ }^{5}$

This model is perfectly compatible with the primary immune response observed at the onset of the disease, e.g. in the guttate psoriasis. Indeed, the development of psoriasis frequently involves inflammation of the pharyngeal lymphoid ring caused by $\beta$-hemolytic streptococcus. The latent period of 2-3 weeks is required for the maturation of effector T-cells and hematogenous dissemination of these cells, as evidenced by multifocal lesions. ${ }^{6,7}$

However, the above model fails to explain some aspects of the disease relapse. For example, the recurrence of plaques is usually observed on the same ("favorite") sites, suggesting the existence of topical immunological memory within the skin. Surprisingly, regional lymph nodes always remain intact, irrespectively of the severity of psoriatic relapse. Altogether, these observations put into the question the exclusive role of lymph nodes in producing effector T-cells. We hypothesized that the psoriatic skin itself may serve as a source of antigen-specific T-cells. This report provides evidence to support this assumption.

\footnotetext{
Received on 06.03.2016.

Approved by the Advisory Board and accepted for publication on 01.08.2016.

* Study conducted at the SM Kirov Military Medical Academy - St.-Petersburg, Russia.

Financial Support: Russian Foundation for Basic Research (grants 13-04-01786, 15-04-01744 and 16-04-0921).

Conflict of Interest: None.

SM Kirov Military Medical Academy - St.-Petersburg, Russia.

N.N Petrov Institute of Oncology - St.-Petersburg, Russia.

Saint Petersburg State Pediatric Medical University - St.-Petersburg, Russia.

(C2017 by Anais Brasileiros de Dermatologia
} 


\section{METHODS}

Patients and biopsies

The study included 41 patients with active psoriasis vulgaris (mean age $43.9 \pm 12.5$ years) who did not receive any systemic or topical treatment at least within 4 weeks prior the examination. Punch biopsies $(6 \mathrm{~mm})$ were obtained from the periphery of psoriatic plaques. 18 of these patients underwent second biopsy in the same skin spot at the time of disease remission. Control samples from 16 healthy individuals included the material leftover after plastic surgeries (mean age $36.1 \pm 12.6$ years). All recruited subjects were required to sign an informed consent form.

\section{Antibodies and immunohistochemistry}

The antibodies used for immunohistochemistry are listed in table 1 . The numbers of $\mathrm{CD}_{4} 5 \mathrm{RA}^{+}, \mathrm{CD}_{45 \mathrm{RO}}{ }^{+}, \mathrm{Ki}^{+} 7^{+}$and $\mathrm{CD} 3 \varepsilon^{+} \mathrm{Ki} 67^{+}$cells in tissue sections were counted at $200^{\times}$magnification on three non-contiguous random grids under high-power field (size $720 \times 530 \mu \mathrm{m}=0.38 \mathrm{~mm}^{2}$ ). The image analysis was assisted by the "UTHSCSA ImageTool 3.0" software. Based on the obtained data, median count of positive cells per field was calculated.

Statistical analysis was performed using the IBM SPSS Statistics, version 20. Wilcoxon-Mann-Whitney test was used to evaluate the differences between the samples of the skin from progressive psoriatic lesions, remission of psoriasis and healthy individuals. A $p$-value of less than 0.01 was considered significant.

\section{RESULTS}

Median count of $\mathrm{Ki} 67^{+}$cells per field in the derma of the groups of patients with progressive disease, patients in remission and healthy individuals was 40,7 , and 3, respectively (Table 2 ). In addition, abundant Ki67 staining was detected in keratinocytes of the basal and lower spinous layers of the epidermis of progressive psoriatic lesions (Figure 1). As expected, the number of proliferating Ki67-positive cells was significantly higher in the derma samples from the patients with progressive psoriatic lesions compared with samples from the patients in remission; meanwhile, the derma of healthy individuals contained very few scattered Ki67 positive cells (Table 2, Figure 1).

Double staining with Ki67 and T-cell marker $\mathrm{CD} 3 \varepsilon\left(\mathrm{CD} 3 \varepsilon^{+} \mathrm{Ki} 67^{+}\right)$confirmed that approximately $30 \%$ of all proliferating cells in the dermis of progressive psoriatic lesions appeared to be T-cells (Table 2 and Figure 2). No proliferating T-cells were detected in the skin of healthy individuals (Figure 1). The skin of patients with psoriasis in remission contained just single proliferating T-cells.

Naive and effector/memory T-cells can be distinguished by the CD45RA/CD45RO staining. We found that the skin of psoriatic patients in acute phase contained significantly higher number of $\mathrm{CD}_{45 \mathrm{RO}^{+}}$effector/memory T-cells (median count: 208) as well as CD45RA ${ }^{+}$naive T-cells (median count: 25 ) compared with patients in remission (median counts 59 and 8, respectively) and healthy controls (median counts 15 and 3, respectively). Interestingly, the spots of regressed psoriatic lesions also contained remarkable number of $\mathrm{CD}_{45 \mathrm{RO}^{+}}$cells (Table 2, Figure 1).

TABLE 1: Antibodies for immunohistochemical analysis

\begin{tabular}{llllll}
\hline Antibody & Cell marker & Antigen (clone) & Antibody dilution & Antigen unmasking & Manufacturer \\
\hline CD3 $\varepsilon$ & T-cell & F7.2.38 & $1: 600$ & Tris-EDTA buffer, pH 9,0 & Thermo Fisher Scientific, USA \\
CD45RA & Naive T-cell & 4KB5 & $1: 200$ & Without processing & Thermo Fisher Scientific, USA \\
CD45RO & Effector/memory T-cell & UCHL1 & $1: 150$ & Citrate buffer, pH 6,0 & Dako, Denmark \\
Ki67 & Proliferating cell & SP6 & $1: 600$ & Tris-EDTA buffer, pH 9,0 & Thermo Fisher Scientific, USA
\end{tabular}

TABLE 2: Immunohistochemical characteristics of the derma of progressive psoriatic lesions, remission of psoriasis and healthy individuals

\begin{tabular}{|c|c|c|c|c|c|c|}
\hline \multirow[t]{2}{*}{ Group } & \multirow{2}{*}{$\begin{array}{l}\text { Patients with pro- } \\
\text { gressive psoriatic } \\
\text { lesions (Pr) }\end{array}$} & \multirow{2}{*}{$\begin{array}{l}\text { Psoriasis patients in } \\
\text { remission } \\
\text { (R) }\end{array}$} & \multirow{2}{*}{$\begin{array}{l}\text { Healthy individuals } \\
\text { (H) }\end{array}$} & \multicolumn{3}{|c|}{ p-value ${ }^{* *}$} \\
\hline & & & & Prvs $R$ & $\operatorname{Pr}$ vs $\mathbf{H}$ & R vs H \\
\hline $\begin{array}{l}\text { Number of positive cells, } \\
\mathrm{X}(\mathrm{x} 0.25-\mathrm{x} 0.75)^{*} \text { : } \\
\mathrm{Ki} 67+\end{array}$ & $40(22-54)$ & 7 (4-13) & $3(2-6)$ & $9.7 \times 10^{-13}$ & $1.33 \times 10^{-14}$ & $8.9 \times 10^{-11}$ \\
\hline $\begin{array}{l}\text { CD3 } \varepsilon+\mathrm{Ki} 67+ \\
\text { T-cells }\end{array}$ & $12(5-17)$ & $2(1-3)$ & 0 & $3.3 \times 10^{-15}$ & $1.3 \times 10^{-14}$ & $2.2 \times 10^{-5}$ \\
\hline $\begin{array}{l}\text { CD45RA+ } \\
\text { (naïve T-cells) }\end{array}$ & $25(15-30)$ & $8(3-11)$ & $3(1-4)$ & $1.7 \times 10^{-13}$ & $4.4 \times 10^{-13}$ & $2.5 \times 10^{-6}$ \\
\hline $\begin{array}{l}\text { CD45RO+ } \\
\text { (effector/memory } \\
\text { T-cells) }\end{array}$ & $208(152-268)$ & $59(41-73)$ & $15(11-21)$ & $3.5 \times 10^{-11}$ & $6.7 \times 10^{-14}$ & $2.8 \times 10^{-8}$ \\
\hline $\begin{array}{l}\text { Number of examined } \\
\text { samples }\end{array}$ & 41 & 18 & 16 & & & \\
\hline
\end{tabular}




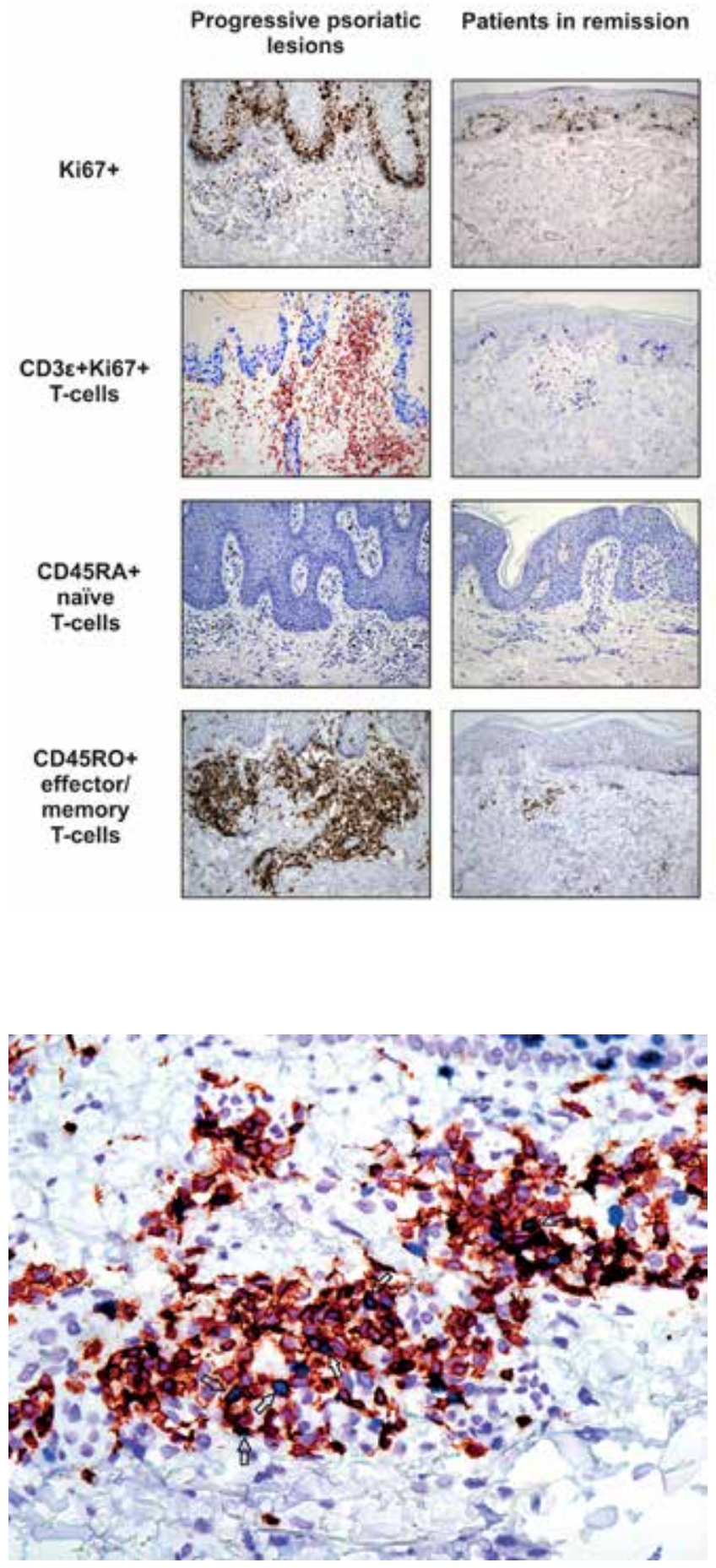

FigurE 2: Double immunohistochemical staining for $\mathrm{CD} 3 \varepsilon+\mathrm{Ki} 67+$ cells (Hematoxylin \& eosin x600)

Thus, the obtained data suggest that proliferation of T-cells in psoriatic patients does not necessarily involve lymph node tissue, but can occur directly in the progressive psoriatic lesions. Apparently, topical effector/memory T-cells $\left(\mathrm{CD} 45 \mathrm{RO}^{+}\right)$serve as a primary source of lymphocyte expansion.
Healthy individuals
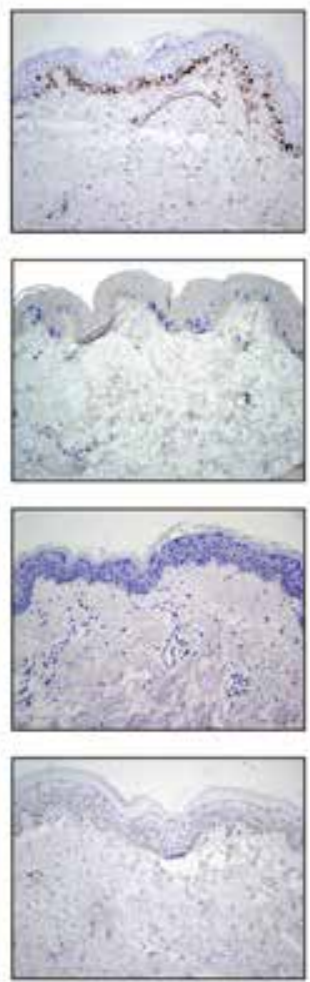

FIGURE 1: Immunohistochemical staining for $\mathrm{Ki} 67+, \mathrm{CD} 3 \varepsilon+\mathrm{Ki} 67+, \mathrm{CD} 45 \mathrm{RA}+$, and CD45RO+ cells in the progressive psoriatic lesions, seemingly intact skin in remission and skin of healthy individuals (Hematoxylin \& eosin x200)

\section{DISCUSSION}

Some of the earlier studies reported that psoriatic lesions are virtually devoid of Ki-67-positive dermal T-cells, however later, in 1990, Nickoloff and Griffiths revealed Ki-67-positive T-cells in psoriatic lesions. ${ }^{8,9} \mathrm{Ki}-67$ expression was shown to occur in T-cells after their migration into the epidermis and interaction with keratinocytes; however, immunohistochemical analysis demonstrated that more than $95 \%$ of the dermal T-cells in psoriatic lesions were Ki-67 negative, suggesting that they were in a resting or non-cycling $\left(G_{o}\right)$ state. The authors concluded that T cells proliferate extra-cutaneously and then migrate to the skin. ${ }^{10}$

Our study demonstrates that progressive psoriatic lesions harbor significant number of proliferating T-cells. Therefore, the skin of psoriatic patients can operate as a lymphoid organ. These results do not conflict with the literature data. Local activation of T-cells is considered to be an important feature of psoriatic skin lesions. Pro-inflammatory cytokine IL17A, being secreted by Th17 cells, is capable to initiate the formation of ectopic lymphoid organs upon chronic inflammation. ${ }^{11,12}$ IL17A stimulates the release of chemokines CXCL13 and CCL19 by fibroblasts and induces the development of lymphoid follicles; the neutralization of IL17A leads to reduction of the size of ectopic lymphoid foci. ${ }^{11,13}$ It was also shown that dendritic cells derived from psoriatic plaques induce in vitro proliferation of T-lymphocytes more effectively than either psoriatic blood-derived or normal skin-derived dendritic cells. ${ }^{14}$

The formation of the ectopic foci of lymphoid tissue, which 
resemble lymphoid follicles, is characteristic for the tissues suffering from chronic inflammation. These foci are usually referred to as tertiary lymphoid organs (TLO). Unlike the lymph nodes, TLO are not encapsulated and therefore engaged in direct interaction with the neighboring tissues. TLO are a landmark of many autoimmune diseases and related conditions, being observed in inflammatory tissues from patients with rheumatoid arthritis, Hashimoto's thyroiditis, recipients of transplanted organs, etc. ${ }^{15-17}$

\section{CONCLUSION}

Our results suggest that the formation of the cellular infiltrate in the skin of patients with psoriasis may occur not only through migration of the immune cells from the peripheral blood, but also by intradermal T-Cell proliferation. Moreover, we found that an excess of $\mathrm{CD} 45 \mathrm{RO}^{+} \mathrm{T}$-cells persists in the regressed psoriatic plaques (i.e., in the seemingly intact skin) in psoriatic patients at remission. These memory T-cells may remain silent for some periods of time, but become activated upon various stimuli and trigger the development of psoriatic lesion. The existence of the intradermal memory T-Cell explains why psoriatic plaques almost always relapse at the sites of the previously regressed lesions. Therapeutic targeting of the specific populations of silent intradermal T-cells appears to be a promising approach for prolonging remission of the disease in psoriatic patients.

\section{REFERENCES}

1. Christophers E. Psoriasis--epidemiology and clinical spectrum. Clin Exp Dermatol. 2001;26:314-20.

2. Perera GK, Di Meglio P, Nestle FO. Psoriasis. Annu Rev Pathol. 2012;7:385-422.

3. Tuettenberg A, Becker C, Correll A, Steinbrink K, Jonuleit H. Immune regulation by dendritic cells and T-Cells--basic science, diagnostic, and clinical application. Clin Lab. 2011;57:1-12.

4. Di Meglio P, Perera GK, Nestle FO. The multitasking organ: recent insights into skin immune function. Immunity. 2011;35:857-69.

5. Clement LT. Isoforms of the CD45 common leukocyte antigen family: markers for human T-cell differentiation. J Clin Immunol. 1992;12:1-10.

6. Owen CM, Chalmers RJ, O'Sullivan T, Griffiths CE. A systematic review of antistreptococcal interventions for guttate and chronic plaque psoriasis. $\mathrm{Br} J$ Dermatol. 2001;145:886-90.

7. Nestle FO, Kaplan DH, Barker J. Review article: Mechanisms of Disease. Psoriasis. N Engl J Med. 2009;361:496-509.

8. Orteu CH, Poulter LW, Rustin MH, Sabin CA, Salmon M, Akbar AN.. The role of apoptosis in the resolution of T-Cell-mediated cutaneous inflammation. J Immunol. 1998;161:1619-29.

9. Ralfkiaer E, Stein H, Bosq J, Gatter KC, Ralfkiaer N, Wantzin GL, et al. Expression of a cell cycle-associated nuclear antigen (Ki-67) in cutaneous lymphoid infiltrates. Am J Dermatopathol. 1986;8:37-43

10. Nickoloff BJ, Griffiths CE. Lymphocyte trafficking in psoriasis: a new perspective emphasizing the dermal dendrocyte with active dermal recruitment mediated via endothelial cells followed by intra-epidermal T-cell activation. J Invest Dermatol. 1990;95:35S-37S.

11. Rangel-Moreno J, Carragher DM, de la Luz Garcia-Hernandez M, Hwang JY, Kusser K, Hartson L, et al. The development of inducible bronchus-associated lymphoid tissue depends on IL-17. Nat Immunol. 2011;12:639-46.

12. Mebius RE. Organogenesis of Iymphoid tissues. Nat Rev Immunol. 2003 Apr;3:292-303.

13. Korn T1, Bettelli E, Oukka M, Kuchroo VK. IL-17 and Th17 cells. Annu Rev Immunol. 2009;27:485-517.

14. Nestle F0, Turka LA, Nickoloff BJ. Characterization of dermal dendritic cells in psoriasis: autostimulation of T lymphocytes and induction of Th1 type cytokines. J Clin Invest. 1994;94:202-9.

15. Armengol MP, Cardoso-Schmidt $C B$, Fernández $M$, Ferrer $X$, Pujol-Borrell $R$, Juan $\mathrm{M}$, et al. Chemokines determine local lymphoneogenesis and a reduction of circulating CXCR4 + T and CCR7 B and T lymphocytes in thyroid autoimmune diseases. J Immunol. 2003;170:6320-8.

16. Rangel-Moreno J, Hartson L, Navarro C, Gaxiola M, Selman M, Randall TD. et al. Inducible bronchus-associated lymphoid tissue (BALT) in patients with pulmonary complications of rheumatoid arthritis. J Clin Invest. 2006;116:3183-94.

17. Nasr IW, Reel M, Oberbarnscheidt MH, Mounzer RH, Baddoura FK, Ruddle NH, et al. Tertiary lymphoid tissues generate effector and memory T-Cells that lead to allograft rejection. Am J Transplant. 2007;7:1071-9.

How to cite this article: Khairutdinov VR, Mikhailichenko AF, Belousova IE, Kuligina ES, Samtsov AV, Imyanitov EN. The role of intradermal proliferation of T-cells in the pathogenesis of psoriasis. An Bras Dermatol. 2017;92(1):41-4. 